ciation of University Professors, with particular attention to sections five and six on Committee Proceedings and Consideration by a Hearing Committee.

4. That the detail chronology and documentation assembled by the fact-finding inquiry be made available to the board for use in such a hearing and that, subject to the approval of the witnesses, the transcriptions of the interviews also be made available. When a hearing committee is appointed, all documentation is to be made available to the principals.

The fact-finding subcommittee was composed of Robert Donahugh, Gerald R. Shields, and Myrl Ricking, chairman. The subcommittee was appointed by the ALA Staff Committee on Mediation, Arbitration and Inquiry, under the provisions of the Program of Action for Mediation, Arbitration and Inquiry. Upon receipt of the Request for Action from Doiron, SCMAI members J. Donald Thomas and David $\mathbf{H}$. Clift, chairman, removed themselves from consideration of the case because they were named as principals in the dismissal. For this inquiry, SCMAI met under the chairmanship of Ruth Frame, with Judith F. Krug and Gerald R. Shields present and constituting a quorum. - E

\title{
ALA / ACRL Representatives at Academic Ceremonies
}

Throughout the year the American Library Association and the Association of College and Research Libraries receive invitations to a variety of academic ceremonies. In recent months members have been asked to represent ALA/ ACRL at inaugurations of college presidents, anniversary celebrations, and dedications of new libraries. On Jan. 20 Mrs. Olive D. Brown attended the inauguration of Bobby Eugene Parker as the twentieth president of Mary Hardin Baylor College in Belton, Texas.

William Graydon Tanner was inaugurated president of Oklahoma Baptist University in Shawnee, Oklahoma on Feb. 23. Clarice French attended the event for ACRL. John Zimmerman represented ACRL at the Centennial Founders Day ceremony of Shepherd College, Shepherdstown, West Virginia on Feb. 27.

John W. Schwoda became the twentieth president of Arizona State University on March 10. Robert K. Johnson was the ACRL repre- sentative at the ceremony in Tempe. The dedication of the new library at Valdosta State College, Valdosta, Georgia took place on April 11 with W. Christian Sizemore in attendance.

Kilborn L. Janecek and Kenneth G. Peterson attended the inaugurations of Thomas J. Clifford and Richard Logan Irby respectively. Mr. Clifford became the eighth president of the University of North Dakota, Grand Forks, North Dakota on April 14 and General Irby was inaugurated superintendent of the Virginia Military Institute, Lexington, Virginia on April 15.

An inauguration ceremony held in honor of Ivan E. Frick, recently named president of Elmhurst College, Elmhurst, Illinois, took place on April 23. Representing ACRL was Kenneth Kirkland.

Keith W. Warne attended the dedication of the Raugust Library at Jamestown College, Jamestown, North Dakota on May 26.

\section{Acronyms in Education and the Behavioral foiences}

\section{by Toyo S. Kawakami}

Now you can find the meaning of practically every abbreviated multiple-word phrase used in education and in the behavioral sciences.

Arranged in strict alphabetical order by acronym, this new reference also serves as a directory of organizations. Also provided is a reverse-order index that distinguishes this book from others in the field. Invaluable to any school, library, educational and behavioral science teaching department, and journal publisher.

\section{This authoritative} compilation includes:

\author{
- organizations \\ - testing instruments \\ - computer and technical terms \\ - periodical title abbreviations
}

ISBN 0-8389-0087-9 (1971)

$\$ 5.75$

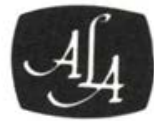

AMERICAN LIBRARY ASSOCIATION

50 East Huron Street • Chicago, Illinois 60611 